\title{
Regional architects: defining Taiwan out?
}

\author{
Catherine Jones
}

\begin{tabular}{|l|l|}
\hline Date of deposit & 06082019 \\
\hline Document version & Author's accepted manuscript \\
\hline Access rights & $\begin{array}{l}\text { Copyright C 2019 Informa UK Limited, trading as Taylor \& } \\
\text { Francis Group. This work is made available online in accordance } \\
\text { with the publisher's policies. This is the author created, accepted } \\
\text { version manuscript following peer review and may differ slightly } \\
\text { from the final published version. }\end{array}$ \\
\hline $\begin{array}{l}\text { Citation for } \\
\text { published version }\end{array}$ & $\begin{array}{l}\text { Jones, C. M. (2019). Regional architects: defining Taiwan out? } \\
\text { Contemporary Politics, Latest Articles. }\end{array}$ \\
\hline $\begin{array}{l}\text { Link to published } \\
\text { version }\end{array}$ & \begin{tabular}{l} 
https://doi.org/10.1080/13569775.2019.1627845 \\
\hline
\end{tabular} \\
\hline
\end{tabular}

Full metadata for this item is available in St Andrews Research

Repository at: https://research-repository.st-andrews.ac.uk/

\section{St Andrews Research Repository}




\title{
Regional Architects: Defining Taiwan Out?
}

\section{Manuscript Document}

\begin{abstract}
The contest between the US and China for who gets to define the region has been developing since the early 1990s. During this time, various competing images of who comprises the region have been seen from the narrow and geographical conception including just the ASEAN states, to wider China-preferred images based on the ASEAN plus three grouping, towards broader perspective favoured by Japan including Australia and New Zealand reflected in proposals such as the Comprehensive East Asian Economic Partnership Agreement. These views of the region and who gets to define it is part of a leadership contest that has evolved to be termed 'competitive regionalism'; this dynamic competition within East Asia has been discussed and debates in this and other regionally focused journals. How do these regional competitions affect the status of Taiwan? This paper makes the argument that the move towards more statebased regional entities and patterns of engagement (regionalisation), which so far have not (yet) adversely affected Taiwan economically, it has produced significant political challenges for Taiwan's ability to continue to be autonomous from the mainland.
\end{abstract}

Keywords: Regionalism, Regionalisation, Taiwan, China.

\section{Introduction}

Public debates on regional integration, and the challenges and opportunities it presents, have increased in prominence. Issues of sub-state actors calls for independence and the problems associated with membership of regional bodies have also entered the debate. For example, in the independence referendum in Scotland in 2014, a significant issue was the continuation or reapplication of membership of the European Union. In 2019, issues of Catalan and Basque independence movements have been hamstrung by the overarching Spanish membership of the EU.

Conversely, within East Asia issues of regional processes of integration have been connected to concerns of China's (PRC) rise, a shifting geopolitical landscape, and the emergence of new regional organisations. It has also centred on the expanded notion of where the region of East Asia is, and which states are included within it (Wilson, 2018:178). In both of these examples, regional composition and component units have been significant determinants of whether supra-state regional bodies have advanced or hampered economic activities and political autonomy. 
In East Asia the new era of competitive regionalism sees China and the US setting out proposals for their own vision of where the East Asian region is and who comprises it. In China, the advent of Xi Jinping as a regionally assertive leader, focusing on developing key projects such as the Asian Investment Infrastructure bank (AIIB) and the Belt and Road Initiative (BRI), presents a view of the region comprised of states geographically positioned within continental Asia, with China as the central driving force of interactions. At the same time, the US is revisiting policies that conceptualise the region as the 'free and open' Indo-Pacific, in which expanded ties between the democracies of the US, Japan, Australia and India (referred to as the Quad) are central to the security and economic framework. Within all the debates on this competition, the precarious position of Taiwan has been overlooked. Yet, given the centrality of sovereign states to both the US and Chinese regional proposals, this then presents a key moment to evaluate Taiwan's position, status, and policies, towards the East Asia region. As around $80 \%$ of Taiwanese trade is with East Asia, it is essential to assess the implications of state-based and state-led patterns of regional engagement for Taiwan's recognition and growth. More broadly, for other regional projects facing issues of internal calls for independence (such as within the EU) it is vitally important

Identifying that in the academic literature there are at least two parallel patterns of regional integration: top-down and state-led regionalism and bottom-up business and demand driven regionalisation, this paper responds to the question: does it matter, and if so how and why, that Taiwan is excluded from the East Asian regionalism and regionalisation processes? In answering this question, the paper makes the argument that, politically it matters as Taiwan loses a mechanism through which it can present itself as autonomous from the People's Republic. Economically, it matters in how Taiwan has responded to these processes, tying businesses into a greater dependence on the PRC. An irony here is that given the patterns of business shown in Taiwan, this closer relationship with the PRC may have been damaging politically without an economic gain sufficient to counter act the effect of weakened political autonomy. As a result, in the processes of both the US and China in seeking to define and demarcate the region, they both define Taiwan out - despite the US centring its quad proposals among the regions great democracies.

In making this argument, the paper proceeds in four parts. First, it considers whit hi is an important debate now. Second, it presents the debates on Taiwan and regional engagement, mapping out the existing arguments and evaluations of Taiwanese engagement. Third it considered how Taiwan's businesses engage or make use of these two regional processes, 
making the argument that Taiwan doesn't suffer economically from this marginalisation. Finally, the paper concludes by arguing that the political costs of marginalisation are high whereas the economic benefits are not sufficient to counter negative political trends. As a result, Taiwan is gradually moving back towards the mainland, and this is reinforced through seemingly unconnected patterns of regional integration.

This paper is positioned within a broadly liberal institutionalist approach at the intersection of debates relating to the function and creation of regions it adopts a neo-functionalist analytical dimension which highlights that in the short term the process of regionalisation may be a preferable policy option, but the potential (and demonstrated) spill over effects in generation joint-political endeavours between the PRC and Taiwan will be detrimental for the maintenance of any form of autonomy or independent agency by the island. However, it also offers a critique of the narrative of liberal interdependence arguing that as interdependence increases between the PRC and Taiwan it makes conflict or tensions in one scenario more likely, but also reaffirms the claims that holistically interdependence in this area will reduce the chances of tensions. In setting up this analysis this paper sets out a map out the possible conceptual tools that could be appropriate for understanding Taiwan's regional position and then compare these approaches to the empirical reality. As demonstrated below there are three main approaches to positioning regional debates in International Relations: Regionalism, Regionalisation, and Globalisation.

Within this broad interdependence frame, this paper adopts an approach of empirical eclecticism - drawing on a range of sources. However, within these sources a significant research claim is also important. As Taiwan has been 'defined out' the places storing data on the territory has also been reduced. In consequence, a part of the process of defining out is also related to shaping 'what data counts' or what sources are appropriate (see for example the nonstorage of Taiwan data at the World Bank after 2014).

\section{A changing Geo-political landscape for Taiwan}

Taiwan's position in international relations has been weakening since it lost the seat for 'China' in the United Nations Security Council in 1971 and the United States switched its international recognition to the People's Republic in a joint communique in 1979. However, despite its absence of international recognition as the legitimate government of China (by all but $16 \mathrm{UN}$ member states states) ${ }^{1}$ Taiwan has been able to maintain informal international recognition and a degree of autonomy in its external affairs. ${ }^{2}$ It has achieved this through a mixture of cultural, 
economic and informal relationships, often relying on crafting pragmatic work-arounds to satisfy the One China Policy. As a result, Taiwan has maintained a claim to de facto rather than de jure independent status, akin to sovereignty.

A part of these claims of independence has been a permissive geopolitical regional reality. Despite the formal shift of US recognition in 1979, Taiwan was continually maintained as an independent economy and an international partner by the US. As the Taiwan relations act states there is a security need to maintain US links with the people of Taiwan.

"Peace and stability in the Western Pacific are in the U.S political, security and economic interest to be maintained. Continued close and friendly commercial, cultural and other relations with the people of Taiwan must be assured." (Taiwan Relations Act, 1979:3)

The act goes on to state that:

"The security provisions are designed to make clear, among other things, that settlement of issues involving Taiwan by use of military force or coercion, such as through interference with economic relationship, by boycotts, embargos, or other means, is unacceptable to the United State." (Taiwan Relations Act, 1979:5)

Within this text, several features become clear. First, that the US through the term 'people of Taiwan' avoids any confusion that the act could be construed as a treaty between sovereign states. Indeed, the act outlines that relations will be conducted through nongovernmental designated entity (Taiwan Relations Act, 1979:4). Second, is that a fundamental feature of this act is how it fits with the broader US approach to the region. Indeed, the US's hub-and-spokes alliance approach in East Asia created an environment that enabled the flourishing of the Taiwanese economy. The hub-and-spokes network through its bilateral nature enabled the creation of a bilateral security arrangement with Taiwan as it was not premised on the engagement of sovereign states. Third, there is an element of strategic ambiguity in the act, to a greater extent than in the US-Japan treaty, that allows for a wide interpretation of what would be considered an attack on Taiwan and what would be determined to be an appropriate US response. This strategic ambiguity is in then a vital element in supporting the deterrence of any hostile action by China.

In contrast, to the approach of the act in 1979, throughout the two terms of the Obama administration and the current period of President Trump, an emergent feature of US 
engagement with the region has been to 'multilateralise' through groupings of states - on economic and security arenas. A move which subtly excludes the involvement of Taiwan. During this period, the US engagement with the region, through the Trans-Pacific Partnership (which it withdrew from in 2017) and through the quad both change and move away from the bilateral hub-and-spokes approach towards a multilateral dynamic.

The Quad, and the emergence of a lexicon of the Indo-Pacific is a crucial signal of how the US conceives of the region and how it would like to develop its future relationship. The quad consisting of the US, Japan, Australia and India - have deepened their military operations and their intelligence sharing since 2016 (Jaishankar, APSI Strategist, 2018). Within this framework the quad is seem by some as being explicitly to contain a rising China and to respond to the Belt and Road initiative. However, although this is heralded as being the US's new commitment to East Asia, it appears to encircle this region rather than embed itself within it. This may be a reflection of lessons learnt in that the US is both treated within concern and a potential threat by states in Southeast Asia (Blaxland and Raymond, 2017), but also that it has faced push back from these states when it has previously tried to multilateralise and impose its construction of the region (see for example the creation of the Southeast Asian Treat Organisation -SEATO)

This circling or demarcation presents a key security problem for Taiwan, the first is that it is within the circle rather than a point on the periphery. In the 1980s and 1990s Taiwan was a crucial 'unsinkable aircraft carrier' in the US's push against China. But, by 2019 it isn't even player. In the briefing slides of the Japanese Ministry of Foreign Affairs, Taiwan is neither identified on maps nor mentioned in the text (MOFA, 2017).

On the economic front, the US vision for the region is equally bleak for Taiwan and demonstrative of a shift. The US is in a unique position to assist it in mitigating the negative effects of the rise of China. However, the US seems reluctant to provide this level of assistance. As can be noted through the trade statistics now available through Taiwan, trade with the US is in decline, but trade with China is growing rapidly. ${ }^{3}$ Similarly, a region-wide non-state based FTA would significantly benefit Taiwan, yet it "could potentially marginalize American commercial interests in the region." (Dent, 2009:167). As a result, the US is likely to resist the development or emergence of credible proposals for such a body.

Taiwan has also seen potential in joining the Trans Pacific Partnership, as a means to embed itself into the region. However, the withdrawal of the US, makes Taiwan's entry, in the absence 
of a membership for the PRC less likely. This replication of the US's 'hokey kokey' style of regional engagement that has characterised the US's Asia policy (Pempel, 2008; Jones, 2013), also weakens Taiwan's regional position, if it depends too heavily on US support.

These shifts in the US comprehension and creation of a new geopolitical reality are striking because they also denote a shift away from Taiwan. In the new US visions of the region Taiwan is not even seen as being a crucible for conflict.

In China's geopolitical regional shaping the position of Taiwan is also problematic. Taiwan is positioned on the horns of a dilemma, whereby the pursuit of an economic relationship with the mainland is necessary but (as discussed below) comes at a cost of political recognition.

\section{How does Taiwan fit into processes of regional integration?}

In this context of competitive regional integration, undeniably, Taiwan's position in international interactions has become increasingly complex considering the overwhelming focus on the regional approach of the PRC. Given the complexity of these interactions there are three sets of arguments about the strategy that Taiwan should adopt: Taiwan should 'go global' and seek global liberalisation of goods and services including bilateral FTAs; Taiwan should 'go regional' and seek to become as embedded as possible in the regional frameworks to safeguard it economic development. The third, is that Taiwan should hope for the ongoing primacy of a process of regionalisation that depends on but also leverages the embedding of Taiwanese businesses into the production cycle. This section briefly presents the different conceptual approaches before going into the detail on how Taiwan fits into them.

The first policy option for Taiwan is that it should seek to engage more deeply with the region, and seek membership of the Trans Pacific Partnership (TPP) and Regional Comprehensive Economic Partnership (RCEP), as well as potentially the Asian Infrastructure Investment Bank (AIIB); in this endeavour Taiwan would be utilising the language that has been adopted in Taiwan's membership of the WTO and Asian Development Bank (ABD) (for example) (Hong, 2011). Both approaches are being followed in Ministry of Economic Affairs (MOEA) and Ministry of Foreign Affairs (MOFA) documents, and both seek to use language to achieve economic goals whilst skirting around issues of statehood.

Yet, the logic of the discussions relating to regional institution are perplexing. Whilst it is undeniably true that there has been a proliferation of regional institutions - many of which Taiwan is not eligible to join ${ }^{4}$ - there are also significant critiques of the efficacy of these 
institutional frameworks (for example the lack of operation of the Chiang Mai Initiative during the global financial crisis in favour of resort to global institutions, or the lack of use of the full provisions of the China-Asean Free trade area-CAFTA, also known as the Asean-China Free trade area - ACFTA). These critiques have been underscored by the under-utilisation of the existing frameworks and Free Trade Agreements (FTAs), ${ }^{5}$ the complexity of the noodle bowl of regional institutions, as well as the potential impotency or irrelevance of regional architectures. $^{6}$

But standing still is no longer an option for Taiwan, particularly if we acknowledge the broadening literature that argues the People's Republic of China (PRC) is taking an increasingly active role in shaping the region ${ }^{7}$ (potentially to the detriment of Taiwan - Barfield, 2011:4; Dent 2009; Cai, 2005).

At the heart of this question is the problem of understanding what makes regional networks and institutions able to achieve their goals. If the answer to this question is that they increasingly rely on the engagement of state-to-state relations within these fora then a lack of membership is a clear barrier for Taiwan's future. However, in the area of trade and economic development, if the answer is that these institutions provide little more than a recognisable shell for activities undertaken and spearheaded by business and conglomerates, then it is conceivable that an absence of membership - whilst ostensibly and psychologically significant - may not be as detrimental as some scholars suggest ( $\mathrm{Wu}, 2008)$. But, this argument may have a temporal dimension, especially if the region wide FTA in the form of the East Asia Free trade area (EAFTA) or Comprehensive Economic Partnership for East Asia (CEPEA) emerges. ${ }^{8}$ Hence there is a growing need to develop a study on the details of interactions with the region. It is insufficient to acknowledge the growth of institutional frameworks and PRC involvement with them. It is necessary to empirically and conceptually explore the details of the engagements that are taking place.

An alternative policy option for Taiwan to mitigate its regional isolation is for it to 'go global'. In other words, Taiwan should aggressively pursue a global liberalisation ${ }^{9}$ and that such a strategy - including seeking increasing numbers of Free Trade Agreements (Barfield, 2011) have two potentially beneficial outcomes. In the short term it may help to reduce Taiwan's dependence on trade with the PRC (Cai, 2005). In the longer term, flourishing and vibrantly competitive economies in both Taiwan and the PRC may provoke more positive cross-straits 
relations (Taipei Times, 2003; Cai, 2005:596-7); thereby, encouraging the subordination of ideology and politics to economic realities.

There are however, also at least three reasons to question the continued relevance of this approach. First, it should be immediately noted that the recommendations in the literature, for this strategy, pre-date the signing of the ECFA agreement between Taiwan and the mainland. There is therefore, a good reason to question whether this policy recommendation remains appropriate in 2018 within the new context of relations with the mainland.

Second, there is also a need to recognise that if FTAs are only able to emerge with the acquiescence of Beijing, or following a similar agreement with the PRC, or only with states that recognise Taiwan, it merely shifts the timing and the political manoeuvrability (and therefore Taiwan's vulnerability) of Beijing in economic relations with Taiwan. As a result, there is an urgent need to weigh the economic gains of FTAs against the political costs.

Third, since the global financial crisis and the subsequent loss in confidence in neo-liberalism, there has been a significant shift away from existing fora for global governance. As a result, China (and other rising states) have focused on developing their own sub-global governance structures with appropriate preferential trade relations (Breslin and Nesadurai, 2018: 198). This presents two urgent problems for Taiwan and its 'go global' policy. First, there is no 'global' to go to, with the stalling of global tariff reductions measures and the development of bilateral agreements, their policy is almost rendered impossible by the changing global context. Second, the movement towards sub-global patterns of governance and particularly regional structures, Taiwan is effectively 'defined out' of being a recognisable autonomous entity. In this context, the Taiwan-China relationship is more crucial to maintaining Taiwan's economy, but it is also more vulnerable to China's bequests.

The final option for Taiwan's regional strategy is to pursue economic regionalisation. That is generate trade ties and supply chain linkages that are inspired and pursued by business and substate actors rather than being state-directed. As Breslin characterises it: "'regionalisation' thus conceived as an undirected process of growing interdependence which originates in the actions of individuals, groups and corporations rather than through the deliberate actions of governments." (2004:4) The relationship between regionalisation and globalisation is therefore not of two mutually exclusive processes but instead, regionalisation 'tames globalisation' (Cooper, Hughes, and de Lombaerde, 2008) or offers a "fall-back or compensatory option 
(Cooper, Hughes, and de Lombaerde, 2008:2) to the process of globalisation or inspires new and innovative forms of regional interaction and governance.

Similarly, Breslin contends that regionalism and regionalisation are not mutually exclusive either, indeed, regionalisation can inspire or make imperative regional governance frameworks (Breslin, 2014:4; Cooper et Al, 2008:8). As noted in the section above, it is possible that as globalisation enables or encourages more cross-straits trade between business entities, formalised agreements may follow to regulate these arrangements. However, as I argue below, whereas regionalisation may be in Taiwan's interests and Taiwan's businesses form an active driver of this process, the outcome of this process - the formalisation of these flows - are not in Taiwan's interests and may exacerbate the island's problems

\section{What type of regional integration is taking place in East Asia?}

In the general trends in debates on East Asian regionalism, there are three propositions: there is no meaningful region formation in East Asia (Smith and Jones, 2007; Sotharith, 2007), there is a degree of soft, non-institutional state directed regionalism (Dent, 2009; Breslin, Higgott, Rosamond, 2002; Kim, 2003; Dorsch, 2003: 498-499; Katzenstein, 2000; Haacke 2003; Collins, 2007; Narine, 2002), there is sub-state regionalisation taking place (Kim, 2003: 185 and 194; Ravenhill, 2009: 235; Severino, 2008).

At a risk of great over simplification, the literature considering economic integration, has converged on a number of elements. First, there is evidence that both state led regionalism and sub-state led regionalisation are taking place. Second, these processes were accelerated in the post Asian Financial Crisis period, and have gradually lost momentum since then (Ravenhill, 2009). Third, the diversity of levels of growth in the region, and differential development patterns necessarily mean that processes of integration are multispeed and multisectoral (Warwick ASEAN Conference, 2014). Fourth, as a result of diversity or approaches and development, there are many different overlapping processes. Fifth, none of the mechanisms for reducing tariffs are being used to their full extent, and as a result there is a gap between the potential for these tariff reduction measures and the achievement of these benefits by businesses.

Although, these kernels of knowledge pervade the literature, the challenge this presents for a non-sovereign state entity such as Taiwan are particular and acute. In this regionalism/globalisation/regionalisation contest, the dominant process, is not merely a case of navigating the many processes simultaneously, but it affects how and whether Taiwan can 
engage as an economic entity, and the national level approaches that it pursues in relation to economic and fiscal policy. For example, if regionalism is the dominant process, then Taiwan is tied to engagement through the sovereign state of the PRC. Whereas, if globalisation or regionalisation are dominant, Taiwan has more options for unilateral, and independent engagement. Yet, from the debates in the literature, discussed below, Taiwan cannot choose both options simultaneously, because of the political damage that occurs in ceding independence to the PRC in the case of regionalism. And as will be shown, regionalisation because it is driven by actors with their own agency cannot be impacted at a national level by politicians, and therefore cannot be easily or readily pursued by state entities.

\section{What is the problem Taiwan faces and why address this now?}

Traditional debates on the region in the Asia-Pacific tend to avoid addressing the issue of Taiwan as it presents conceptual and empirical challenges for understanding and assessing regional interactions. Crucially, in discussions that do tackle Taiwan's regional engagement the political has become subordinate to the economic. Indeed, the assumption of these engagements has been that Taiwan will experience ever-reducing political leverage and manoeuvrability within its own periphery, but this assumption still needs further academic scrutiny.

The state of play for Taiwan in 2018, then, looks particularly bleak. At a global level the glacial pace of WTO liberalisation, mean that Taiwan is unable to power its economy forwards and remain an attractive destination for companies and foreign direct investment in the future. At the regional level, although processes of regionalism appear to be heavily criticised and slow moving, the tilt is increasingly towards China. Even processes of regionalisation that are being institutionalised through the emergence of an increasing number of bilateral Free Trade Agreements, are moving in China's favour.

On the diplomatic front in 2017-2018, Taiwan experienced some of its worst years in terms of its international recognition, possibly since it lost its Security Council seat in 1971. In 2017, Panama withdrew from diplomatic relations with Taiwan in favour of the PRC. In addition to the losses noted above, in the Taipei Times, there was a report that Paraguay may also be positioning itself to swap recognition (May 2018). Other states are also being placed under pressure to change their recognition to the mainland, for example, the Pacific Island of Palau has been forced to close down operations of an airline based they as a result of China banning 
tour groups from using the operator because of the Island's recognition of Taiwan (Business insider, 19 July 2018).

Similarly, in terms of semi and informal recognition (Jones, 2014), Taiwan has also been negatively affected. In February and March 2018, both British Airways and Lufthansa were criticised in China for implying that Hong Kong and Taiwan were separate entities from the country of China. As of July 2018, the British Airways country list renders Taiwan as 'TaiwanChina', and Lufthansa listed it as Taiwan, China. In May 2018, it emerged that Norway has responded to pressure from China to class Taiwanese visitors (particularly students - but not only students) as 'Chinese Nationals' in its visa and immigration system (Asia Times, 2018). Given the need for Taiwan to use informal channels for diplomacy and engage with media and businesses to gain recognition (Rawnsley, 2000:106-133), these losses are substantial.

Prior to these two years of hardship for Taiwan it has increasingly lost recognition through a number if 'minor but indicative' changes to its ability to engage with international organisations. For example, in 2014 the World Bank stopped reporting data from Taiwan. In looking at the diplomatic losses since the signing of the cross straits agreement there has been a marked downturn in Taiwan's international clout.

The question then arises, that if Taiwan loses diplomatically by trying to establish bilateral FTAs and also formalise trade relations with the mainland, are the economic benefits sufficient to counteract these actions and can regional based policies sufficiently counter the negative effects of this de-recognition?

This narrative then presents an increasingly pressing problem for Taiwan: what policy should it pursue with regards to its economic and political engagements at the regional (and global) level? What effects will different policies have? The next section considers the processes of regional integration and then considers how Taiwan engages with them, evaluating the two policies that have dominated Taiwan's approaches for the past forty years: go regional, or go global.

\section{Do any of these three approaches benefit Taiwan Economically?}

Since the 2008 Global Financial Crisis (GFC), regional and global dynamics have been changing. Taiwan was impacted by the GFC particularly because North America and Europe were badly affected and demand for the types of products Taiwan produces (ICT equipment) slumped; Taiwan's economy has always been tied into global (not just regional) trading 
patterns (Chen et al, 2011:1050). The stymieing of the World Trade Organisation's Doha round has resulted in a push for a proliferation of bilateral and sub-global trading relationships (Young, 2014:9). In the past Taiwan has been reticent to develop these links but is now looking for a greater number of opportunities to create preferential trade links (Armanovica, 2013:4; Chen et al, 2011:106; Armstrong, 2013:100). Taiwan so far has created nine free trade agreements or economic cooperation agreements, including a cross-straits agreement (ECFA) with the PRC and an investment protection agreement with Japan, which could develop into a full FTA. Taiwan has also been clear that it would seek to join regional trade bodies such as the Trans-pacific Partnership (TPP) and the Regional Comprehensive Economic Partnership (RCEP). This approach by Taiwan has been termed 'going regional': that is the development of preferential trading relations at the regional level and the pursuit of bilateral trade agreements.

However, academics have raised concerns about the effects of the pursuit of these trading relationships; on the one hand they argue that regional trading preferential trade agreements remain poorly utilised, so the absence of Taiwan is not a major economic obstacle (Armstrong, 2013:107), they caution that emerging pluri-lateral trade proposals such as the TPP, would only affect a small percentage of Taiwan's exports (Liu, 2016), but the political costs for Taiwan's engagement is high, particularly as these relationships are only possible with the express permission or at least acquiesce of the PRC (Young, 2014) and will affect the cordiality of relations between Taipei and Beijing (Lin, 2016:321). Hence, because of the changing trading environment and the emergence of competitors to Taiwan's traditional place in supply chains (notably from China and Southeast Asia) there is a need to explore the effects of regional integration processes that affect Taiwan's economic growth.

This changing economic environment also presents political challenges for Taiwan that are affected by the approaches of the government of Taiwan to ensure economic growth. Previously, through its economic weight, Taiwan has been able to enhance its international political leverage; by gaining recognition as an independent 'economy' of Chinese Taipei. Moreover, because of the advanced level of Taiwanese exports, its own patterns of business development, and a lack of institutionalised regional economic governance, Taiwan's non-state status has not yet adversely affected its economic performance. As a result, it made little difference to Taiwan economically that it lost its international recognition. Its economy continued to grow and flourish (Winkler, 2008:487). 
However, economic agreements are not only, indeed may not chiefly be about economic benefits (Magcamit, 2015: 93). The first step change for Taiwan's position was in 1991 when the ASEAN states signed a regional free trade agreement, creating a change in the costs for production in Taiwan. However, the bigger change arose in 1997 in the wake of the Asian Financial Crisis. During the crisis China emerged as a friend to Southeast Asia (Ba, 2006); by not devaluing the Reminbi, China protected its Southeast Asian neighbours from a greater economic disaster. China's relationship to the region had changed from being a dragon in the back garden to an economic benefactor (Ba, 2003; Cheng, 2001: 425; Giang, 2011: 160). Since then, China has emerged as a potential regional leader (Dosch, 2010:61-63). From the late 1990s then, trade between Southeast Asian states and China grew significantly, as a result, even in the sub-state region building process of regionalisation the trend shifted from business with Taiwan to business with China. Even though China has been viewed more cautiously since 2010, when it was claimed it had become more assertive in the South China Sea, China's regional largesse and new projects related to the AIIB and BRI, both further enhance China's economic weight in the region.

In 2002 when Taiwan joined the World Trade Organisation (WTO) it was seen as a major shift in Taiwan's fortunes (Magcamit, 2015:87; Winkler, 2008:47). Membership had two central gains for Taiwan. First, membership of the international body, even as an economy, demonstrated informal recognition that Taiwan was autonomous from the mainland. Second, membership had an economic benefit which meant that by pursuing global trade liberalisation on a non-state basis in the WTO, regional and state-based liberalisation processes that disenfranchised Taiwan would be mitigated - for example it also allowed for the EU to have a presence in Taiwan (Winkler, 2008:481; Armanovica, 2013:4). However, on both of these counts the potential gains from Taiwan's membership of the WTO have not been achieved. According to Winkler, recognition of Taiwan at the WTO is insufficient for Taiwan to be seen as a sovereign actor in trade matters, because as Taiwan's membership was timed to follow China's undermining claims to autonomy (Winkler, 2008: 483).

Furthermore, since progress on trade liberalisation within the WTO framework has been frozen Taiwan has since had to seek out alternative trading relationships in order to both serve an economic imperative and a political need. However, since both China and Taiwan joined the WTO, China's economic volume and competitive edge over Taiwan has increased, and as a result Taiwan's global position has further weakened. In evaluations of future trading links analyses increasingly contend that relations with Taiwan will become marginalised, except in 
instances where Beijing grants Taiwan 'permission' to complete an economic agreement with a state that Beijing already has an agreement with. For example, the free trade agreements between Taiwan-Singapore, and Taiwan-New Zealand, were able to be finalised only because Beijing already had similar agreements, and because the government in Taipei was willing to engage and develop a service and trade agreement with Beijing.

Since the DPP's Tsai Ing-wen came to power in Taipei, the relations between China and Taiwan have become increasingly strained. As a result, new trading agreements between Taiwan and other states that were being considered, are now unlikely to move forwards. As Xi Jinping adopts a more assertive foreign policy and places increasing emphasis on the "nearabroad'; routes to Taiwan being able to maintain its trade autonomy are rapidly reducing. A further political hit for Taiwan was the loss of recognition, by Bukina Faso, El Salvador and the Dominican Republic (BBC, 2018; Rich, 2009) (which happened to be a state Taiwan already had an FTA with).

Finally, China's overtures to Taiwan, in terms of both the population and the government have added to the pressure on the government in Taipei to reach trade deals with the PRC, even to the point of damaging their long-term ability to maintain their appearance of independence. For example, as Tang argues, "Should this development continue Taiwan would be less and less able to withstand this attraction. According to functionalist theory the likeliness of using military force should be decreasing if the interactions between the two sides are increasing." (Tang, 2006:561). However, as noted in a series of articles in the Journal of Contemporary China, the population in Taiwan has reacted to the negative effects of overtures from Beijing (Liu and Li 2016; Zhong, 2016; Pan, Wu and Chang, 2016).

In the FTAs that have been signed it is notable that Taiwan could only sign an agreement after the mainland had an FTA in place. In some way this may offer hope to Taiwan, in that its quasistatehood may not be a permanent barrier to the development of traditionally state-based agreements, but they will potentially always have to be sub-ordinate to an agreement with the PRC. For example, using the indicative case of Costa Rica, despite the loss of recognition and the absence of an FTA, it is still the largest trading partner for Taiwan in Central America.

In terms of Taiwan's trade with ASEAN, across all ten states trade is increasing, and the only states with which Taiwan has a trade deficit are Indonesia and Brunei. ${ }^{10}$ Overall, then TaiwanAsia trade seems to have demonstrated some resilience to the forces of state-based FTAs. Even the concerns around the signing and later implementation of the China-ASEAN FTA (CAFTA) 
in January 2010 have been unfounded as economic relations between Taiwan and ASEAN continue to grow. Although, CAFTA is still being gradually implemented across the ASEAN states, and Vietnam, which is at the forefront of Taiwan's regional engagements through the conglomerates (for example China Plastics) was not one of the early harvest states. Hence, there may be a negative impact of Taiwanese-Vietnamese trade because of a more competitive sector in China that benefits from an FTA but this is yet to come to realization. For example, it is crucial to recall that the ASEAN FTA that was initially developed in the 1990s has been heavily criticized for not producing the typical (i.e. Western) levels of regional integration and growth. If this is the case the issue of Taiwan's (non)involvement is less connected with economic hazards and more concerned with recognition or ideational issues. Indeed the initial reports suggest the slow implementation of CAFTA, will stymie the negative effects on Vietnamese-Taiwan economic relations, (Ye, 2008; Thanh, 2011), it may be too early to make the prediction that in the long term it will not severely damage the volume of trade between these states. As a result, if this is the case then the claim at the start of this paper that the issue for Taiwan is less structural or economic and more recognition and therefore social would take discussions and solutions to a different place.

Even though it may be too early to tell if Taiwan does experience a direct trade loss in the wake of CAFTA in relation to Vietnam, the issue raised here is a valid one. The premise of arguments that not being in regional FTAs and integration processes is a bad thing for Taiwan is based on an assumption that trade and the growth of GDP are linked to these mechanisms. Indeed as Thanh notes: "the bigger danger is that Taiwan will be isolated from the economic unity process in East Asian once FTAs between ASEAN and Japan, Korea, India, Australia and New Zealand come into effect." (Thanh, 2011:36).

The issue with the TPP was (in part) that the US didn't want to negotiate with potential additional members until the draft has been accepted by the founding members. However, in addition to this there is also an issue with the status of the PRC regarding the TPP; China is not a founding member and its relationship and enthusiasm is a little ambiguous. The problem of which is that the TPP is a crucible of tensions between the US and China in economic terms, seen by some as being the 'anyone but China club' and others as being a pragmatic move towards a $21^{\text {st }}$ Century trade agreement, the criteria for which China didn't meet - yet. Since the US withdrawal from the TPP, and the progress made by the other remaining members, this has opened the possibility that China could at some stage join, but Taiwan's potential membership would only follow a membership by China. As Bellows argues, Taiwan's eventual 
membership of the TPP will be in part contingent on either China's own membership or at least acquiescence to such a move, as he puts it "China can simply convince one or two of the original signors not to approve Taiwan's application ...” (2015: 118). However, previously Bush and Meltzer have noted that accession to a completed TPP could be on the basis that consenting states would extend agreements to the newcomer, whereas non-consenting states may not (2014:8). However, Richard Bush has also noted elsewhere that Taiwan's membership would need to be sequenced with China's entry (Bush and Meltzer, 2014:15). Most significantly, however, Bush and Meltzer note that the TPP could act as a catalyst for internal review and change to Taiwan's business structures, rules and regulations - as noted later these internal patterns of Taiwanese business may be more important than membership of regional bodies.

Although, China has been keen to prevent Taiwanese membership, the US has been lukewarm in its support, in 2014, the house foreign affairs committee merely noted Taiwan's interest in becoming a member (Bellows, 2015:119) Suggests that although the US may not be keen to have China on board, the lack of an invitation to Taiwan may imply that there is a desire to make a policy already disliked in China less acrimonious.

\section{Taiwan's Business links - the regionalisation potential}

Although, the institutional and formal processes associated with regionalism have attracted several scholar's attention and suggests that there is some deliberative agency on the part of China in defining Taiwan out of the region - at least in other respects that does not imply that Taiwan is a sub-region of the PRC itself. The image of the regional business relationships is potentially more confusing and hence more interesting. In looking at the developments of the conglomerates in Taiwan and their regional (indeed global) interactions there seems to be a pattern of flourishing relations that are not greatly adversely affected by the absence of FTAs in the region.

Despite, this precarious international situation (above), Taiwan has been able to emerge as an economic powerhouse, and one of the Asian Tiger economies or Newly Industrialised Economies (NIEs). Taiwan's success was built on a number of elements: it was a prime destination for foreign direct investment because it had a young, educated, and cheap labour force, intellectual property protections, and an emerging democratic political structure. Government policies and development practices that were broadly aligned to the development model of Japan and South Korea also aided Taiwan's growth as a trade entity. Government 
management of economic relations and investment, relatively small public sectors and an export orientation (Kuznets, 1988: S17). These factors ensured that it was attractive to manufacturers, particularly those seeking to make components of hi-tech products (Armanovica, 2013:7).

Moreover, as Taiwan's domestic businesses emerged they tended towards being companies that could be incorporated into supply chains rather than developing their own global brands for finalised products. As a result, although many component parts are made in Taiwan there are few international competitive brands. For example, in the Forbes Global 2000 ranking of international companies, the highest ranked company is Hon Hai Precision at $113^{\text {th }}$; although an international company it produces components for other global brands'. ACER one of the most well-known Taiwanese brands only enters this list at rank 1822 (Forbes, 2018). This approach to development has led to Taiwan being one of the most export-trade dependant economies in the world (Armanovica, 2013:6).

In 2016, Taiwan remained US's $10^{\text {th }}$ largest trade partner, (OUSTR, 2018). The emergence of a domestic market for higher end goods within Taiwan enhanced its attractiveness as a partner for trade not just a location for manufacturing. At the regional level, the absence of preferential trading agreements, and peer competitors also ensured that Taiwan's position whilst gradually weakening in the political realm, its economic growth has continued and trading relations have remained relatively strong. Through these trade and business (rather than state-centric) links Taiwan maintained an ability to present itself as an independent entity. However, the future looks bleak. Despite the appearance of a good economic outlook for Taiwan, fundamental challenges and challengers are emerging, that have the potential to undermine the basis for Taiwan's growth.

The first of these elements is the emergence of triangular trade relationships, whereby Southeast Asian or Chinese partners are also destinations on the way to finalised products being exported to Europe and North America (Liu, 2016). A crucial example here is the case of Apple. During the ascendency of this tech giant, Taiwan formed a vital element in the supply chain, the most basic components for Apple products are made in Shenzhen in the PRC, these components are then shipped to Taiwan for processing as this offered Apple a highly skilled labour force and better protections for its intellectual property rights. Finally, products were shipped to the US for finishing and to ensure they fell under the provisions of US intellectual property laws. This supply chain has ensured that even though some business and skills have 
been transferred to the PRC, Taiwanese sub-contractors were still in business. However, in 2018, a report emerged that claimed that this integral position in the supply chain could move to the US ${ }^{11}$
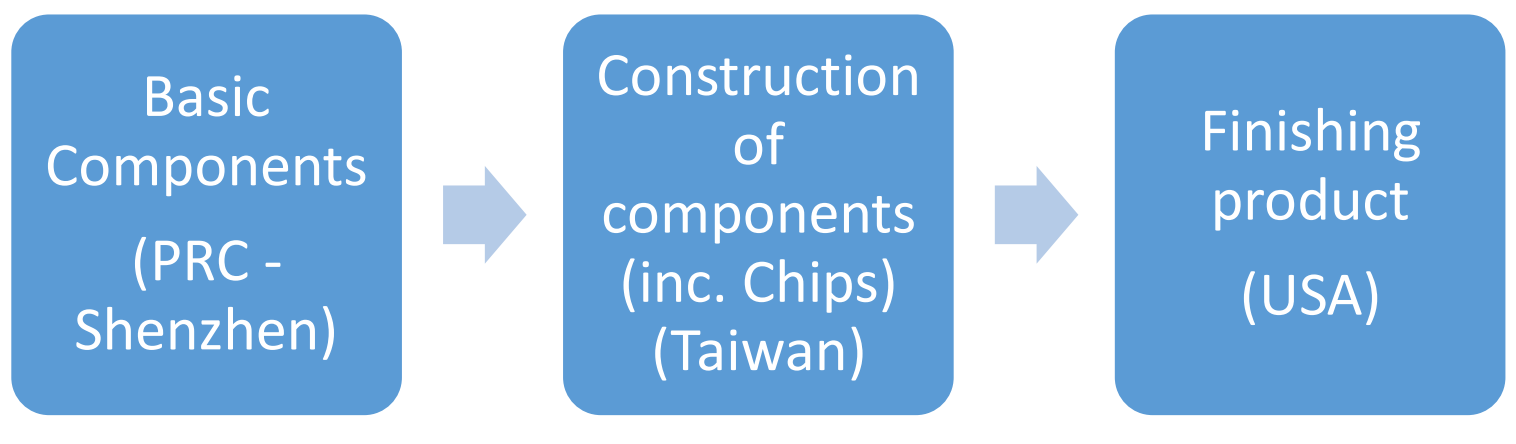

In this dynamic, both the absence of Taiwan's inclusion into regional trading relationships and its absence of bilateral US or EU trade agreements, reduces the attractiveness of Taiwan as a trading partner. This is also a potential outcome of the trade war between China and the US, in these tensions, US companies are increasingly concerned with the predictability of goods and costs of manufacturing in Asia and are increasingly being reported to be looking to increase US-based production. As Bellows argues that Taiwan's position in these supply chains is becoming more precarious (2015:123). As a result, the trade tensions between the US and China, as well as the region-building dynamics are informing and weakening the position of Taiwan.

A significant aspect of the business relations between the Taiwanese government and businesses is reflecting in the development of relations. In the Republic of Korea the chaebols were heavily supported by the government and connections between the state and businesses were actively encouraged. However, because of the desire of the KMT government in Taiwan to walk a line between capitalism and communisms, these links were less developed in Taiwan (Ferdinand, 2012:231-232). Hence, the businesses are more adept at operating and creating deals without explicit government supported interventions.

This is further demonstrated by the Going Southward policy of the 1990s, when the Government encouraged the business community to increase ties with Southeast Asian nations to avoid an overreliance on the growing Chinese economy (Yang, Hsuao, and Tai-Shang: 217). However, although this policy was enacted for political, as well as economic reasons, the small 
and medium enterprises that developed business links in Southeast Asia were driven by economic incentives (Yang, Hsiao, and Tai-Shang:218).

However, as a result of economic and business preferences, the mainland with its inviting prospects of the division of labour has continued to attract Taiwanese firms despite the risks, as Segre notes “... Taiwan's excellent economic performance may in the long run be endangered by the country's outsourcing to China of her production of OEM (original equipment manufacturing) and ODM (original design manufacturing)." (Segre, 2008:7) As a result, the issue of Taiwanese firm's investment and dependency on China became a major issue in Taiwanese politics, but it is also demonstrably resistance to being used as a tool to further political needs. As businesses seek to maintain a competitive advantage and pursue their own profitability and growth, their willingness to conform to the long-term political needs reduce.

This is becoming a significant problem for Taiwan and its domestic policies, as the business patterns are resilient to government preferences, yet, political parties are increasingly pressured to resist the dominance of China. This can be seen in events since the signing of the aforementioned ECFA, when the completion of the agreement sparked resurgence for the DPP in the 2014 Local Elections, in which the DPP routed the KMT, the party in power. In a similarly vein, after the election of the DPP President Tsai Ing-wen, who rode to power on an anti-China mandate, tried to rejuvenate a New Southward Policy (NSP) since 2016 in order to mitigate the dependence on China, businesses have not conformed and switched production to Southeast Asia. Indeed, even since the early 2000s (pre-dating the NSP) bigger business has become pro-China supporters (Tian, 2006: 111) despite the larger popular animosity to the mainland. As the government in Taiwan has only limited leverage over the private sector (Tian, 2006: 101), coordination issues, and problems in providing sufficient funding are more evident within Taiwan (Huang, 2018: 57) this ensures that the government faces both international and domestic political challenges. Moreover, it is unavoidable to notice that that this NSP is following major engagements and economic agreements between the PRC and Southeast Asia, making it more likely to be successful, it is also noticeable that some key aspects of the NSP are aimed at being 'softer' and are structured to be a less direct economic challenge to China (Huang, 2018: 55). Hence, although the policy intention is to mitigate reliance on China, it is in part enabled and successful because it follows Chinese investments and regional construction that then feeds and supports the 'One China' policy. 
These policy positions show that Taiwanese officials understand the political detriment of economic benefits in their relationship with the PRC. However, the failures, show the difficulty of legislating to influence regionalisation. The business proposition of investing in China proved too attractive to Taiwanese firms that need to find every advantage they could, to maintain market positions in the global trade competition with Newly Industrialised Economies (NIEs) rivals (Tian, 2006: 107). Perversely, if companies hadn't used the China option in such a way, Taiwan wouldn't have developed as much and would have been in a much more vulnerable position vis-à-vis the mainland.

In addition, a greater portion of business in Taiwan is conducted by small and medium enterprises (Tian, 2006: 93), than in the other developmental states of Japan and Korea. Even in larger firms the pattern of growth maintains links to their strengths as SMEs. Unlike big businesses in Japan and South Korea, these larger entities tend to be "family based business groups" that have a "tendency to diversify once they are established in a principle line of business." (Tian, 2006:90) As such they have more in common with the structures of large business seen in conglomerates in Indonesia (Ferdinand, 2012). As a result, these SMEs (and even bigger businesses) have a lot in common (in terms of business practices) with their associates in Southeast Asia, in particular the fact that they have "predominantly remained small, flexible and adaptable." (Ferdinand, 2012: 213) Indeed a reason for the continued success of Taiwanese business has been their ability to adapt quickly, get needed products to the market fast, and to respond to the needs of bigger business. They have demonstrated an ability to position themselves effectively within regional supply chains, so that their partners in Southeast Asia gain from the interaction, value is added in Taiwan, and the final product destination is in North America or Europe (Yang, Hsiao, and Tai-Shang, 220). They have done this by remaining small and agile and largely free from intervention by the government, unlike their counterparts in South Korea (Segre, 2008:27-28). Therefore, in the process of regionalisation these businesses have an ability to adapt to the surrounding business climate and overcome the negative consequences of competitive FTAs developing.

In a further bonus to developments with Taiwan is the issue of trust in relations between business partners - the enduring relations between people (often cited as being a feature of China commerce 关系) opens up the options of which China business people trust more (Segre, 2008:29). In the precarious position in the middle of supply chains occupied by Taiwan this trait acts as an additional mitigating factor for business vulnerabilities. However, this is seen 
as a Chinese trait not solely a Taiwanese trait, as a result, it will also be a benefit to businesses from the mainland investing in Southeast Asia.

Because Taiwan never "aggressively used the financial system as an industrial tool" (Hun Joo Park, 2001: 854) it also means that business development has been more independent and (ironically) more capitalist, hence the survival mechanisms of these businesses may also contribute to their lack of exposure to the downsides of being outside a formal FTA/Institutional architecture - having not previously drawn on the state as a provider of or mitigate for market based issues. Examples of this is the developments of relations between Taiwan and its Southeast Asian business partners, these enduring relations, and the ability of partners to effectively side-step the downsides of not having a formal FTA. However, these links depend on businesses being able to maintain their agile structures and not being heavily impacted by tensions between Taiwan and China as well as negative consequences of political ambitions by the government of Taiwan.

In addition, the development of Taiwan's business as partially isolated from the international trade fluctuations, which allowed them a buffer to the 1997 AFC (Yu-Shan WU, 2007) - may also provide a buffer from the potential (over) exposure to the growth of China as a competitor, but also an over dependence on China as a trading partner in the wake of the ECFA. However, many commentators argue that the independence of businesses is also their vulnerability, as they are resistant to usual government mechanisms to support their trade relations.

In exploring the nature of Taiwanese business and in evaluating the prospects of both the go regional and go global strategies, two things then become apparent. First, despite the intentions of the government in Taiwan to try and use businesses as a tool for political gain, businesses have remained focused on decisions based on economic rather than political incentives. As a result, attempts by the government have largely failed. Second, neither the go global nor the go regional strategy has ensured greater or even maintained recognition by other states or organisations. In contrast, the signing of the ECFA and other ties with China have been a boost for business.

\section{Conclusion}

This paper has addressed the question, does it matter, and if so how and why, that Taiwan is excluded from the East Asian regionalism and regionalisation processes? The overall argument presented is that it matters diplomatically by not being recognised, however, Taiwan's strategies to redress this problem have had the counter effect and ensure Taiwan is increasingly 
seen as a dependent of the mainland. Economically, because of the nature of Taiwanese businesses combined with the weakness of regional economic engagement, exclusion from regional trade agreements has not yet had a significant effect on trade, particularly in light of the fact that $83 \%$ of Taiwan's trade is regional (ADB, 2017: 52).

The more significant finding of this paper echo's Lin's argument that Chinese strategies on regionalism, will start to squeeze out Taiwan increasingly through a grand strategy of engagement (Lin, 2016). As a result, of its exclusion from the region the political costs for Taiwan are already being felt. Its ability to present itself as an autonomous economic entity is rapidly diminishing. This is the case, despite the nascence of regionalism and regionalisation processes in East Asia. Although this nascence will mean the economic costs of Taiwan's exclusion are likely to emerge more gradually, as the economic agreements between East Asian states start to flourish and Taiwanese businesses will slowly become displaced by Chinese and Southeast Asia rivals able to leverage cost savings from regional agreements. Furthermore, this will also diminish Taiwan's ability to brand itself as an independent state.

Even though, to date, Taiwan has sought to mitigate the potential negative economic effects of this exclusion, by seeking bilateral free trade agreements (with Singapore and New Zealand, as well as with states that still politically recognise Taiwan), and through memberships of broader trading agreements (such as the World Trade Organisation and APEC). However, by looking in detail at these arrangements it becomes evident that they tie Taiwan closer to the People's Republic than they appear, because they only arise after similar agreements with the People's Republic.

As a result, Taiwan's long-standing practice of seeking to avoid international isolation by pragmatically pursuing trade autonomy and recognition in trade and financial international fora is fast becoming obsolete. Both of Taiwan's recent policies of 'going global' and 'going regional' have led to Taiwan being further embraced and influenced by the PRC. Ironically, then, Taiwan should potentially hope for regional processes of sub-state regionalisation to dominate relations and not result in formal state-to-state or institutional agreements. In this context, although processes of regionalisation lack efficacy and are unable to be controlled by the government directly, the best option for Taiwan would be to try and use national policies alongside its traditional business patterns and links, to remain an attractive place of business, and a key trading state. However, this is a solution driven by a context that is out of Taiwan's control but heavily influenced by the preferences of the PRC. 


\begin{abstract}
${ }^{1}$ Taiwan is recognised as being the legitimate government of China by 17 states: Paraguay; Belize; Guatemala; Haiti; Honduras; Nicaragua; Saint Lucia; St Vincent; St Kitts; Kiribati; the Marshall Islands; Nauru; Palau; Solomon Islands; Tuvalu; Holy See; and Eswatini. The Dominican Republic switched recognition to the PRC on $1^{\text {st }}$ May 2018 and El Salvador switched recognition in August 2018.

${ }^{2}$ Taiwan maintains informal cultural offices and diplomatic relations with a number of states that formally recognise the People's Republic of China as the legitimate government. These states include the US and the UK. Taiwan has also been able to achieve institutional recognition as an 'economy' at both the World Trade organisation and within the Asia Pacific Economic Cooperation forum (APEC). Furthermore, it is able to compete at the Olympic Games as 'Chinese Taipei', through the approval of the International Olympic Committee.

${ }^{3}$ Full trade details can be found through the SOURCE: DIRECTORATE GENERAL OF CUSTOMS, MINISTRY OF FINANCE, ROC, data is available from https://cus93.trade.gov.tw/FSCE030F/FSCE030F?menuURL=FSCE030F report IDs were: FSC3030R reports generated $2^{\text {nd }}$ May 2018.

${ }^{4}$ Taiwan is a member of a number of regional organisations including APEC and the ADB.

${ }^{5}$ These discussions of underutilisation are evident across commentators, for example see Kawai and Wignariaja, 2010; Shino, 2012; The Economist, 2014).
\end{abstract}

${ }^{6}$ For the range of debates on ASEAN as a Security Community see for example: Acharya, 2001; Jones and Smith, 2002; Jones, 2015

${ }^{7}$ The importance of the region for China has been discussed in a number of academic volumes for example: Zhang, 2011.

${ }^{8}$ Forecasts for the boost in GDP for states involved in these agreements are available in Kawai and Wignaraja, 2010:21.

${ }^{9}$ Indeed, as noted by ROC MOEA there is a need for Taiwan to pursue liberalisation in order to continue and diversify growth.

${ }^{10}$ For details see Bureau of Foreign Trade, 2016, ROC-ASIA trade statistics, available from http://www.trade.gov.tw/english/Pages/List.aspx?nodeID=664 last accessed 22 $2^{\text {nd }}$ June 2016.

${ }^{11}$ Jennings, Ralph. 2018. 'If Apple Shifts Production To The U.S., Taiwan's Tech Hub Will Suffer' Forbes available https://www.forbes.com/sites/ralphjennings/2018/09/26/if-apple-shifts-production-to-the-u-s-taiwanstech-hub-will-suffer/\#6c911b03ae75 accessed 23 April 2018.

\title{
Bibliography
}

Acharya, A. (2001) Constructing a Security Community in Southeast Asia: ASEAN and the Problem of Regional Order Routledge: London.

ADB (Asian Development Bank) 2017, ‘Asian Economic Integration Report 2017' available https://www.adb.org/sites/default/files/publication/375196/aeir-2017.pdf accessed 17 July 2019.

Armanovica, M., 2013. Taiwan - The Risk of Marginalisation: Economic situation and trade relations with the EU, DG EXPO/B/PolDep/Note/2013_239, October 2013, pp. 1-20. 
Armstrong, S-P. 2013 Taiwan's Asia Pacific economic strategies after the Economic Cooperation Framework Agreement, Journal of the Asia Pacific Economy, 18(1), pp. 96-114

Asia Times. 2018. 'Taiwanese labeled as Chinese in court action against Norway' Asia Times, published 31 May 2018, available https://www.asiatimes.com/2018/05/article/taiwaneselabeled-as-chinese-in-court-action-against-norway/ accessed 27 June 2019.

Ba, Alice. 2003. 'China and ASEAN: (Re)navigating Relations for a $21^{\text {st }}$ Century Asia' Asian Survey, 43(4) pp.622-647.

Ba, Alice. 2006. 'Who's socializing whom? Complex Engagement in Sino-ASEAN relations' The Pacific Review, 19(2), pp.157-179.

Barfield, C. 2011. Taiwan and East Asian Regionalism, American Enterprise Institute, AEI Conference Paper, November 2011, pp. 1-29.

BBC. 2018. 'Taiwan looses diplomatic ally as Dominican Republic switches ties to China' BBC Online, published on $1^{\text {st }}$ May 2018, accessed online at http://www.bbc.com/news/worldasia-china-43958849 last accessed 9th May 2018.

Bellows, Thomas J. 2015 "The Trans-Pacific Partnership and Taiwan: Possibilities and Difficulties." American Journal of Chinese Studies, 22, pp. 115-127.

Blaxland, John and Greg Raymond. 2017. 'Tipping the balance in Southeast Asia: Thailand, the United States and China' The Centre of Gravity Series, November 2017, available http://bellschool.anu.edu.au/sites/default/files/uploads/2017-11/cog_37.pdf accessed 16 May 2019.

Breslin, Shaun, Higgott, Richard and Rosamond, Ben, 'Regions in comparative perspective', in Shaun Breslin, Christopher W. Hughes, Nicola Philips and Ben Rosamond (eds.) New Regionalisms in the Global Political Economy: Theories and Cases, London, Routledge, 2002, pp. 1-19.

Breslin, Shaun. 2004. 'Greater China and the political economy of regionalism' East Asia: An International Quarterly. 21(1) pp.7-23

Breslin, Shaun and Helen Nesadurai. 2018. 'Who Governs and How? Non State Actors and Transnational Governance in Southeast Asia', Journal of Contemporary Asia, 48:2, pp.187203.

Bush, Richard C, and Joshua Meltzer. 2014. 'Taiwan and the Transpacific Partnership' Brookings Center for East Asia Policy Studies, 3, published January 2014.

Chan, Tara Francis. 2018. 'China has forced a Pacific airline to close down because of diplomatic ties with Taiwan’ Business Insider. Published 19 July 2018, https://www.businessinsider.com.au/palau-airline-closes-over-anger-from-china-abouttaiwan-ties-2018-7 accessed 27 June 2019.

Cai, Kevin, (2005) 'The China-asean Free Trade Agreement and Taiwan' Journal of Contemporary China, 14(45) pp.585-597 
Chiang, M-H. 2011. 'Cross-Strait Economic Integration in the Regional Political Economy', International Journal of China Studies, 2(3) pp. 681-700.

Chen, S-H., Liu, M-C., \& Wen, P-C. (2011) The ECFA and its expected effect on cross-strait trade and investment: a Taiwanese perspective, China Economic Journal, 4(2-3), pp. 105-1024.

Cheng, Joseph Y.S. 2001. 'Sino-ASEAN Relations in the Early Twenty-First Century', Contemporary Southeast Asia 23(3), pp.420-451.

Collins, A. 'Forming a Security Community: lessons from ASEAN', International Relations of the Asia-Pacific, (2007) 7(2) pp.203-225

Cooper, Andrew, Hughes, Christopher W., and de Lombaerde, Philippe (eds.) Regionalisation and Global Governance: The Taming of Globalisation?, London, Routledge, 2008.

Dent, Christopher. 2009. 'Japan, China and East Asian Regionalism: Implications for the European Union' Asia Europe Journal, 7, pp.161-178.

Dosch, Jörn. 2010. 'China and Southeast Asia: A New Regional Order in the Making?' in Lowell Dittmer and George T. Yu (eds), China, the Developing World and the New Global Dynamic Lynne Rienner: London.

Dosch, Jörn. 2003. 'Changing security cultures in Europe and Southeast Asia: Implications for inter-regionalism’ Asia Europe Journal, 1, pp.483-501.

The Economist, 2014. 'FTAs in South-east ASIA: Towards the next generation', An Economist Intelligence Unit Report, full text available from http://www.economistinsights.com/countriestrade-investment/analysis/ftas-south-east-asia last accessed 23rd June 2015.

Ferdinand, Peter. 2012. Governance in Pacific Asia: Political Economy and Development from Japan to Burma, Continuum: New York.

Financial Times. 2018. 'Taiwan opposition ditiches pro-China overtures ahead of poll' Financial Times, online at https://www.ft.com/content/515fc4f0-51bd-11e8-b24ecad6aa67e23e accessed 9th May 2018.

Forbes. 2018. 'Forbes Global 2000: Taiwan's largest companies' available http://www.economywatch.com/companies/forbes-list/taiwan.html accessed 16 May 2018.

Giang, Bui Truong. 2011. 'ASEAN and China Relations: Seeking for Economic Cooperation' in Zhang Yunling (ed) Making New Partnership: A Rising China and its Neighbours Social Sciences Academic Press: China, and Paths International: London, pp.153-176.

Haacke, Jurgen, ASEAN's Diplomatic and Security Culture: Origins, Development and Prospects, London, Routledge, 2003, Chapters 1 and 2, pp. 16-51.

Huang, Kwei-Bo. 2018. 'Taiwan's New Southbound Policy: Background, Objectives, Framework, and Limits' Revista UNISCI / UNISCI Journal, 46 (Enero/January 2018) pp.4768.

Hun Joo Park. 2001. 'Small Business in Korea, Japan and Taiwan' Asian Survey, Vol. 41 No. 5, September/October 2001. pp. 846-864. 
Jaishankar, Dhruva. 2018. 'The real significance of the Quad' APSI Strategist. Published 24 October 2018. https://www.aspistrategist.org.au/the-real-significance-of-the-quad/ last accessed 27 June 2019.

Jones, C. 2013. 'Hokey, Kokey, Hegemony' Conference Paper for BISA Annual Conference, 2013, Birmingham.

Jones, Catherine. 2014. 'Constructing great powers: China's status in a socially constructed plurality' International Politics, 51(5) pp.597-618.

Jones, C., (2015) 'Great Powers, ASEAN, and Security: Reason for Optimism? Pacific Review 28(2) pp.259-280

Jones, D.M. and Smith, M.L.R. (2002) 'ASEAN's Imitation Community’ Orbis 46(1) pp. 93109

Katzenstein, Peter, 'Regionalism and Asia', New Political Economy, vol. 5, no. 3, November 2000, pp. 353-68.

Kim, Joongi. 2003. 'Sub-regionalism, regionalism, trans-regionalism. Implications for economic integration and international trade policies' Asia Europe Journal, 1, pp.183-196.

Kawai, Masahiro and Ganeshan Wignaraja, (2010), Asian FTAs: Trends, Prospects, and Challenges, Asian Development Bank, ADB Economics Working Paper Series, No.226 published October 2010.

Kuznets, Paul W, (1988), An East Asian Model of Economic Development: Japan, Taiwan, and South Korea, Economic Development and Cultural Change, 36, issue 3, p. S11-43.

Lin, G. 2016. Beijing's New Strategies Towards a Changing Taiwan, Journal of Contemporary China, 25(99), pp. 321-335.

Liu, Da-Nien. 2016. 'The Trading relationship between Taiwan and the United States: Current trends and the outlook for the future' Brookings, op-ed, first published, November 2016, available online at https://www.brookings.edu/opinions/the-trading-relationship-betweentaiwan-and-the-united-states-current-trends-and-the-outlook-for-the-future/ accessed $9^{\text {th }}$ May 2018.

Liu Frank C.S. and Yitan Li, 2016. 'Generation Matters: Taiwan's Perceptions of Mainland China and Attitudes towards cross-strait trade talks' Journal of Contemporary China [online first]

Magcamit, M., and Tan, A., 2015. Crouching tiger, lurking dragon: understanding Taiwan's sovereignty and trade linkages in the twenty first century, International Relations of the Asia Pacific 15 pp. 81-112.

MOFA, 2017. 'Priority Policy for Development Cooperation FY2017' https://www.mofa.go.jp/files/000259285.pdf accessed 16 May 2019.

Narine, Shaun. 2002. Explaining ASEAN: Regionalism in Southeast Asia, Boulder, Colorado: Lynne Rienner. 
OUSTR. 2018. Office of the United States Trade Representative, US-Taiwan Trade Facts, available online at https://ustr.gov/countries-regions/china/taiwan accessed, $9^{\text {th }}$ May 2018.

Pan, Hsin-Hsin, Wen-Chin Wu, and Yu-Tzung Chang, 2016. 'How Chinese citizens percieve cross-strait relations: Survey Results from Ten Maajor Cities in China, Journal of Contemporary China

Pempel, T.J. 2008. 'How Bush Bungled Asia: How Unilateralism, Militarism and Economic Abdication Weakened the US Across Asia', The Pacific Review, 21(4) pp. 57-72.

Rawnsley, Gary. 2000. Taiwan's informal diplomacy and propaganda, Palgrave Macmillan, Basingstoke, UK.

Ravenhill, John. 2009. 'East Asian Regionalism: Much ado about nothing?' Review of International Studies, 35, pp.215-235.

Rick, Timothy, 2009. 'Status for Sale: Taiwan and the competition for diplomatic recognition' Issues and Studies, 45(4) pp.159-188.

Segre, Sandro. 2017. Business Groups and Financial Market: A Weberian Analysis, Routledge, New York.

Severino, Rodolfo C. 2008. 'The Emerging region of East Asia', Asia Europe Journal, 5, pp.447-454.

Shiino, K. 2012. 'Overview of Free Trade Agreements in Asia' in Kazunobu Hayakawa (ed.) Cause and Consequence of Firms' FTA Utilization in Asia, BRC Research Report No.9, Bangkok Research Centre, IDE-JETRO, Bangkok.

Smith, Michael and David Jones. 2007. 'Making Process Not Progress: ASEAN and the Evolving East Asian Regional Order' International Security, 32(1) pp.148-184

Sotharith, C. 2007. ASEAN- China and Asia Regionalism: Implication to Taiwan, CICP Working Paper No. 17, June 2007, pp. 1-18.

Tang, S., New Trends in the cross-Strait relations between China and Taiwan, AEJ, Vol 4 (2006), pp. 555-562.

Taiwan Relations Act, 1979.' U.S-Taiwan Relations Act' Available at https://www.cia.gov/library/readingroom/docs/CIA-RDP85-00003R000100050016-5.pdf last accessed 16 May 2019.

Taipei Times, CNA, Kaoshuing,, 'Leamer urges Taiwan for push for free-trade pacts' Taipei Times, 22 $22^{\text {nd }} \quad$ February 2003, available http://www.taipeitimes.com/News/biz/archives/2003/02/22/0000195527 last accessed 29th June 2015.

Thanh, Dang Xuan. 2011. 'AEC, ECFA, and Vietnam-Taiwan economic relations' paper presented at Seminar on 'Taiwan - Vietnam Economic Cooperation: Moving Towards the 2015 Vision of ASEAN Economic Integration', Hanoi, Vietnam, August 16, 2011, available http://www.aseancenter.org.tw/upload/files/outlook005-06.pdf accessed 16 May 2019. 
Tian, John, 2006. Government, Business, and the Politics of Interdependence and Conflict across the Taiwan Strait, Palgrave, New York

Warwick ASEAN Conference, 2014.

Wilson, Jeffrey. 2018. 'Rescaling the Indo-Pacific: From Economic to Security Driven Regionalism in Asia' East Asia, 35, pp.177-96.

Winkler, S. 2008. 'Can trade relations make a sovereign? Taiwan-China-EU relations in the WTO’ Asia Europe Journal, 6, pp. 467-485.

Wu, Linjun(2008)Taiwan and the ASEAN Economic Community: A Context for Economic Statecraft in an Asian Regional Free Trade Area .Issues \& Studies,44(4), pp.99-128.

Wu, Yu-Shan. 2007. 'Taiwan's Developmental State: After the Economic and Political Turmoil' Asian Survey, Vol. 47 No. 6, November/December 2007.

Yang A.H., Hsiao HH.M. (2016) Tai-shang (Taiwan Business) in Southeast Asia: Profile and Issues. In: Kim YC. (eds) Chinese Global Production Networks in ASEAN. Understanding China. Springer, Cham.

Ye Yi-Lun, 2008. 'Taiwan's Response to International Trade Challenges in the Face of the Free Trade Waves in Asia' Taiwan Institute of Economic Affairs, accessed http://english.tier.org.tw/eng_analysis/fs001.asp accesed 16 May 2019.

Young, J. 2014. Space for Taiwan in regional economic integration: Cooperation and partnership with New Zealand and Singapore, Political Science, 66(1), pp. 3-22.

Zhang Yunling (ed.) (2011) Making New Partnership: A rising China and its neighbours, Social Sciences Academic Press, China and Paths International Ltd. UK.

Zhong, Yang 2016. 'Explaining National Identity Shift in Taiwan' Journal of Contemporary China, 25(99) pp.336-352.

Zhao, Hong. 2011. 'Taiwan-ASEAN Economic Relations in the Context of East Asian Regional Integration' International Journal of China Studies, 2(1), pp.39-54 